\title{
Drukarnia i księgarnia przyszkolna Gimnazjum Wołyńskiego i Liceum Krzemienieckiego (1811-1832)
}

Gimnazjum Wołyńskie w Krzemieńcu utworzył Tadeusz Czacki we współpracy z Hugonem Kołłątajem, otrzymawszy zgodę cara Aleksandra I. Uroczyste otwarcie tej placówki odbyło się 1 X 1805 r. Była to szkoła średnia o specyficznym systemie nauczania. Składała się z czterech „klas”, w których nauka trwała po roku, a potem z trzech dwuletnich „kursów”. Tak zatem cykl kształcenia wynosił 10 lat. Czacki, będący od 1803 r. wizytatorem szkół guberni wołyńskiej, podolskiej i kijowskiej, powołując Gimnazjum Wołyńskie w Krzemieńcu, do końca życia (zmarł w 1813 r.) był jego szczególnym opiekunem i protektorem, dbającym o rozwój tej placówki. On też skompletował kadrę nauczycielską, ludzi o wysokich kwalifikacjach i aspiracjach naukowych. W szkole istniała bogata i cenna biblioteka, której trzon stanowił księgozbiór zamkowy króla Stanisława Augusta Poniatowskiego, funkcjonowały też gabinety, m.in. fizyczny, chemiczny, mineralogiczny, jak i ogród botaniczny. Czacki z czasem powołał również w Krzemieńcu szkołę mechaników i geometrów rządowych. Gimnazjum Wołyńskie uzyskało status Liceum w 1819 r., już po śmierci Czackiego. Dzięki istnieniu Gimnazjum, późniejszego Liceum w Krzemieńcu, miasteczko to stało się centrum naukowym, kulturalnym i towarzyskim Wołynia. Sama szkoła zaś słynęła z wysokiego poziomu nauczania, nacisk kładziono m.in. na nauczanie języków obcych, a także - mimo zaborów - na wychowanie patriotyczne. Szkoła przetrwała do 1833 roku, po czym decyzją władz carskich została zamknięta, a jej bibliotekę i kolekcje przewieziono do Kijowa, do nowo utworzonego Uniwersytetu św. Włodzimierza, gdzie też znaleźli posady krzemienieccy profesorowie'1.

* Dr hab., prof. Uniwersytetu Jana Kochanowskiego w Kielcach, Instytut Bibliotekoznawstwa i Dziennikarstwa, Zakład Historii Prasy i Książki, 25-406 Kielce, ul. Świętokrzyska 21 D.

1 E. Danowska, Tadeusz Czacki 1765-1813. Na pograniczu epok i ziem, Kraków 2006. 
Hugo Kołłątaj jeszcze przed otwarciem Gimnazjum Wołyńskiego opracował Rozporządzenie kursów nauk mających się dawać w gimnazjum, gdzie w paragrafie 12. napisał: „Przez wzgląd na wielką odległość 3ch gubernij, wołyńskiej, podolskiej i kijowskiej od Uniwersytetu Wileńskiego, dozwala się założyć drukarnię przy gimnazjum krzemienieckiem, w której dawne xiążki elementarne, lub na nowo poprawione, albo nowo wydane i przez Uniwersytet Wileński ogłoszone, dla wygody 3ch rzeczonych gubernij drukować na zawsze ma być wolno"2. O sprawie założenia drukarni przy działającej już wówczas szkole w Krzemieńcu, Kołłątaj nadmienił w liście do Tadeusza Czackiego wysłanym 14 kwietnia 1806 r. ze Stołpca na Wołyniu, gdzie wówczas mieszkał: „O drukarni także trzeba myśleć, bo bez tej wielka jest niewygoda"3.

Okolice Krzemieńca w dawniejszych, a nawet zamierzchłych już czasach, nie były pozbawione drukarni. W tym mieście, przy monasterze Trzech Króli, od 1637 r. istniała ruska drukarnia, ufundowana przez założycieli klasztoru - cześnika wołyńskiego Ławrija Drewnickiego i chorążego Daniłę Malińskiego. W 1648 r. podczas zajęcia Krzemieńca przez Kozaków, drukarnia uległa zniszczeniu bądź została wywieziona. W znajdującym się nieopodal Poczajowie, w 1618 r. spod pras wędrownej drukarni należącej do archimandryty Cyryla Stawrowieckiego wyszedł pierwszy druk poczajowski. W latach trzydziestych XVII w. miasto doczekało się stałej oficyny, która powstała przy klasztorze bazylianów. Po trzecim rozbiorze Polski, Poczajów znalazł się w granicach państwa rosyjskiego, co wpłynęło na zahamowanie działalności wydawniczej oficyny, lecz nie spowodowało zamknięcia warsztatu. Uzyskawszy carski przywilej, drukarnia przystąpiła do normalnej pracy, drukując książki m.in. dla Gimnazjum Wołyńskiego w Krzemieńcu ${ }^{4}$. Utworzenie przy szkole drukarni okazało się koniecznością wobec faktu, że drukarnia poczajowska bardzo niedbale drukowała powierzane jej rękopisy ${ }^{5}$.

W chwili powoływania gimnazjum w Krzemieńcu, Hugo Kołłątaj i Tadeusz Czacki preliminowali jego wydatki, pomijając jednak koszty założenia drukarni, „która zdaje się być koniecznie potrzebna w Krzemieńcu”, a przewidziana głównie dla drukowania książek elementarnych. Uważali bowiem, że drukarnia powinna się sama utrzymać, a nawet przynosić dochód przeznaczany na potrzeby szkolnej biblioteki, a konkretnie zakup pism periodycznych ${ }^{6}$.

Jak napisał Joachim Lelewel: „W Krzemieńcu geniusz Czackiego chciał mieć gimnazjalną typografię własną i biegał oświeceniu ziomków poświęcający się Czacki za tym płodem miejscowym nader czynnie"?.

2 X. Hugona Kołłątaja Korespondencja listowna z Tadeuszem Czackim, wyd. F. Kojsiewicz, Kraków 1844, t. 2, s. 12-13.

3 Tamże, t. 4, s. 119.

4 Drukarze dawnej Polski od XV do XVIII wieku, z. 6: Małopolska - Ziemie Ruskie, oprac. A. Kawecka-Gryczowa, K. Korotajowa, W. Krajewski, Wrocław-Kraków 1960, s. 129, 185. Bogumił Samuel Linde odnotował, że wydano tam m.in. Grammatykę słowiańską w 1638 r., zob.: J. S. Bandtkie, Historya drukarni w Królestwie Polskiem i Wielkim Xięstwie Litewskiem, Kraków 1826, t. 1, s. 321.

5 M. Rolle, Ateny Wołyńskie. Szkic z dziejów oświaty w Polsce, Lwów-Warszawa-Kraków 1923, s. 182.

${ }^{6}$ X. Hugona Kołłątaja..., t. 2, s. 40.

7 J. Lelewel, Bibliograficznych ksiąg dwoje, Wilno 1923, t. 1, s. 226. 
Jak wynika z listu Tadeusza Czackiego do generała ziem podolskich Adama Kazimierza Czartoryskiego z 12 sierpnia 1810 r., finalizacja prac nad przygotowaniem drukarni do działalności miała się ku końcowi, a wiązano z nią wielkie nadzieje na druk jak największej liczby wartościowych dzieł ${ }^{8}$. Z kolei w liście z 7 listopada tegoż roku zapowiadał księciu Adamowi Kazimierzowi opublikowanie „kopii rękopisu Marcina Galla z wariantami według biblioteki poryckiej” oraz „wyciągu do historii polskiej z oryginałów i godnych wiary kopij”. Przyszłość pokazała, że do tego nie doszło, a Tadeusz Czacki swoim zwyczajem więcej obiecywał, niż mógł dotrzymać.

Otwarcie drukarni nastąpiło dopiero 3 marca $1811 \mathrm{r}$. Jej zadaniem było wydawanie podręczników na potrzeby gimnazjum i innych szkół z terenów guberni wołyńskiej, podolskiej i kijowskiej. Pragnieniem Czackiego było, aby podręczniki szkolne i inne materiały pomocnicze drukowano w Krzemieńcu, rezygnując już z usług drukarni zakonnych, np. w Poczajowie, Łucku, Berdyczowie czy Żytomierzu. Fundatorami drukarni krzemienieckiej byli hr. Filip Nereusz Olizar i Filip Plater, następca Czackiego na stanowisku wizytatora, którzy sfinansowali zakup domu na stałą siedzibę, sprowadzenie urządzeń i czcionek oraz zakup papieru na początek działalności. Drukarnia oraz księgarnia, o której jeszcze będzie mowa, początkowo były umieszczone w domu Ożarowskich, poza murami szkolnymi, a następnie $w$ dawnym klasztorze bazylianów. $Z$ czasem znalazły miejsce w domu zwanym „wieżą”, nieopodal zabudowań pobazyliańskich. Dom ten pierwotnie należał do miasta i popadał w ruinę, a szkoła odkupiła go od magistratu krzemienieckiego w 1818 r. za sumę 770,75 rubli srebrem. Wszystkie wydawnictwa ukazujące się $w$ tej drukarni podlegały cenzurze szkolnej i Uniwersytetu Wileńskiego. Cenzorem z ramienia szkoły krzemienieckiej był zazwyczaj dyrektor lub prefekt. Nad nimi był jednak Komitet Cenzury Wileńskiej, który musiał wszystko zatwierdzić. Drukarnię nadzorował z ramienia szkoły tzw. rządca drukarni, zwany też nadzorcą, którym przez dłuższy czas był ksiądz Alojzy Osiński, który wykładał m.in. literaturę polską. Drukarnia miała stałe zlecenia ze szkoły. Początkowo były to pisma okolicznościowe, programy nauczania, odezwy, mowy, zarządzenia władz szkolnych itp. Z czasem zaczęto drukować podręczniki „szkołom przez Uniwersytet Wileński do użycia wskazane” i tzw. „seksterna”, czyli skrypty, rzadziej prace naukowe i dzieła literackie, głównie profesorów szkoły krzemienieckiej ${ }^{10}$. Drukarnia miała obowiązek przesyłania sześciu egzemplarzy każdej pozycji do Departamentu Oświaty w Petersburgu ${ }^{11}$.

Należy dodać, że otwarcie drukarni przy Gimnazjum Wołyńskim w Krzemieńcu było wyrazem ambicji protektorów tej szkoły. Głośno domagał się tego Tadeusz Czacki, projektowi sprzyjał też książę Adam Kazimierz Czartoryski, pragnący,

8 Biblioteka Czartoryskich w Krakowie (dalej: Bibl. Czart), rkps 6035, nlb.

9 M. Danilewiczowa, Życie naukowe dawnego Liceum Krzemienieckiego, [w:] Krzemieniec. Ateny Juliusza Słowackiego, red. S. Makowski, Warszawa 2004, s. 33.

10 A. Szmyt, Gimnazjum i liceum wołyńskie w Krzemieńcu w systemie oświaty Wileńskiego Okręgu Naukowego w latach 1805-1833, Olsztyn 2009, s. 203-204; E. Danowska, Tadeusz Czacki 1765-1813..., s. 316; J. S. Bandtkie, Historya drukarni..., s. 321.

11 Biblioteka Naukowa PAU i PAN w Krakowie, rkps 2813, k. 67 (list Jana Śniadeckiego do Tadeusza Czackiego z 4 VI 1811 r.). 
by publikowano w niej historyczne materiały źródłowe $z$ dawnej biblioteki królewskiej, zakupionej przez Czackiego na potrzeby szkoły w Krzemieńcu ${ }^{12}$.

W drukarni szkolnej krzemienieckiej początkowo publikowano głównie druki urzędowe, choć przed rokiem 1817 wydano w niej prace Jana Potockiego Principes de chronologie pour les temps antérieurs aux Olympides (cz. 1 - 1813 r., cz. 2 - 1815 r.) oraz Alojzego Osińskiego: O życiu i pismach ks. Piotra Skargi (1812 r.) i O życiu i pismach Tadeusza Czackiego (1816 r. $)^{13}$. Warto też wspomnieć jeszcze o innych ważniejszych publikacjach tej oficyny, m.in. profesora historii powszechnej i geografii starożytnej Józefa Uldyńskiego Geografia starożytna stosowana do dzisiejszej z krótką wiadomością o chronologii podług przedniejszych w tym względzie wzorów dla pożytku uczącej się młodzi ogłoszona (1819 r.), profesora języka greckiego Michała Jurkowskiego np. Chrestomatia grecka (1815) i Antologia grecka (1815). Drukowano też mowy Tadeusza Czackiego jako wizytatora szkół i protektora szkoły w Krzemieńcu na rozpoczęcie i zakończenie roku szkolnego, czy też mowy na okoliczność jego śmierci, np. Adama Radzimińskiego Mowa na uczczenie pamięci Tadeusza Czackiego (1813). Warto też wspomnieć o wydrukowanej w 1811 r. pozycji Jana Nepomucena Lerneta Fundusz na czterech uczniów przy Gimnazjum Wołyńskiem utrzymywać się mających.

Jak wyglądały początki drukarni i księgarni krzemienieckiej od chwili założenia, wobec tego, że nie zachowały się materiały, niestety niewiele wiemy. Dopiero od 1817 r. mamy więcej informacji. Wtedy to, aby mieć lepszą możliwość druku i sprzedaży książek na miejscu, postanowiono sprowadzić znanego i doświadczonego wydawcę oraz księgarza warszawskiego Natana Glücksberga. Warto przybliżyć nieco jego sylwetkę. Natan Glücksberg (1780-1831) był księgarzem, drukarzem i nakładcą warszawskim. Zaliczał się do bogatszych, postępowych i zasymilowanych Żydów w tym mieście, do którego jego ojciec przybył z Niemiec. Miał nawiązane stosunki księgarskie z Mediolanem, Lipskiem, a także z Firminem Didot w Paryżu. Przez pewien czas prowadził skład główny na Polskę szeregu wydawnictw francuskich. Księgarze polscy ze wszystkich ziem byli jego kontrahentami, a on sam posługiwał się tytułem „księgarza i typografa uprzywilejowanego Królewskiego Warszawskiego Uniwersytetu". Natan Glücksberg pod koniec 1817 r. wezwany został przez grono profesorskie szkoły w Krzemieńcu, będąc poleconym przez księcia Adama Jerzego Czartoryskiego, kuratora Wileńskiego Okręgu Naukowego. W 1818 r. zajął się drukarnią i księgarnią jako „drukarz i księgarz Liceum Wołyńskiego". Jego dziećmi byli: Krystian Teofil (księgarz, wydawca i typograf Uniwersytetu Wileńskiego), Henryk Emanuel (uczeń Gimnazjum i Liceum Wołyńskiego, tłumacz, publicysta), Emanuel August (księgarz), Gustaw Leon (uczeń Gimnazjum i Liceum Wołyńskiego, księgarz i wydawca) ${ }^{14}$. Zarządcą drukarni i założonej tam giserni ustanowił najstarszego syna Krystiana Teofila

12 D. Beauvois, Wilno - polska stolica kulturalna zaboru rosyjskiego 1803-1832, Wrocław 2010, s. 174. Autor podaje dzień 31 marca 1811 r. jako datę otwarcia drukarni.

13 Glücksberg Natan, [w:] Słownik krzemieńczan 1805-1832, wstęp i oprac. W. Piotrowski, Piotrków Trybunalski 2005, s. 103.

${ }_{14}$ H. Pfeiffer, K. Świerkowski, Glücksberg Natan, [w:] Polski Słownik Biograficzny (dalej: PSB), t. 8, s. 94-95; Glücksberg Natan, [w:] Słownik krzemieńczan..., s. 102-103. 
(1796-1876), późniejszego księgarza wileńskiego, który założył też księgarnię w Kijowie ${ }^{15}$. Mniemać należy, że drukarnia, gisernia i księgarnia w Krzemieńcu stanowiły tylko część rozległych interesów Natana Glücksberga. Niemal od początku swych związków ze szkołą, na czele krzemienieckiej filii postawił najstarszego syna Krystiana Teofila, a po nim drugiego syna - Gustawa Leona ${ }^{16}$.

Wszystko na to wskazuje, że treść umowy z Natanem Glücksbergiem podejmującym się obowiązków w Krzemieńcu opracował książę kurator Adam Jerzy Czartoryski lub też odbyło się to pod jego kierunkiem. W papierach księcia zachował się bowiem brulion zatytułowany „Punkta do zawarcia kontraktu z Imć Panem Glücksbergiem". W projekcie umowy napisano, że otrzymuje on tytuł księgarza i typografa Gimnazjum Wołyńskiego. Zobowiązuje się założyć w Krzemieńcu drukarnię o dwóch prasach; w umowie określono również rodzaje czcionek, jakimi powinien dysponować. W razie potrzeby ma sprowadzić więcej pras i czcionek. Glücksberg zaręczył sprowadzenie jak najlepszych pracowników, w tym korektorów. Z funduszów edukacyjnych otrzyma pożyczkę na $6 \%$ w skali rocznej na rozruch drukarni. Może drukować i sprzedawać wszystkie książki naukowe i elementarne zalecane szkołom przez Uniwersytet Wileński, ponadto relacje z popisów, rozprawy i programy, jednak w cenie nie wyższej niż przyjęta w Wilnie. Gimnazjum Wołyńskie zastrzegło sobie prawo pierwszeństwa w drukowaniu, a także bezpłatne otrzymanie po jednym egzemplarzu każdej wydrukowanej pozycji. Na lokal dla glücksbergowskiej drukarni i księgarni przewidziano miejsce zwane wieżą. Zasiedli go nie później niż we wrześniu 1819 r. Umowa przewidziana była na 6 lat, a Glücksberg zawsze miał mieć pierwszeństwo przed konkurencją. Władze Gimnazjum zapewniały go o wszelkich ułatwieniach, także o tym, że drukarnie berdyczowska i poczajowska nie będą drukowały ksiąg elementarnych. Obiecały również wspierać i protegować księgarnię, ułatwiać import i przewóz książek. Glücksberg z kolei obiecał, że będzie przedstawiał dyrektorowi Gimnazjum do wglądu wszelkie katalogi wydane swoim nakładem, za transport książek będzie płacił ze swojej kasy. Autorzy umowy wymogli na drukarzu i księgarzu, że ceny książek w Krzemieńcu mogą być tylko o 10\% wyższe w porównaniu z warszawskimi, a drukowane przez Glücksberga w Warszawie - o 5\%. Brulion umowy liczy 27 paragrafów ${ }^{17}$. Ktoś, niestety nie wiadomo kto, zweryfikował te paragrafy, omawiając je, komentując i objaśniając. Podkreślone zostało, że tytuł typografa i księgarza Gimnazjum Krzemienieckiego jest nader zaszczytny, a Glücksberg otrzymuje szereg ułatwień i przywilejów. Pada wniosek, by umowę z nim zawrzeć nie na 6 lat, lecz na $12^{18}$.

Właściwy kontrakt został zawarty „przez dyrektora szkół gubernii wołyńskiej z P. Glücksbergiem na założenie drukarni i księgarni w Krzemieńcu" dnia 26 lipca 1818 r. Jest on bardzo obszerny, składa się z 33 paragrafów. Poza wymienionymi powyżej najważniejszymi ustaleniami i zasadami, dodano tu, że Glücksberg będzie się stosował do wszystkich wymogów cenzury. "Oddział drukarni” omawiają

15 A. Śnieżko, Glücksberg Krystian Teofil, PSB, t. 8, s. 95-96.

16 Glücksberg Natan, [w:] Słownik krzemieńczan..., s. 103.

17 Bibl. Czart., rkps 5455, k. 285-291.

18 Tamże, k. 293-299. 
paragrafy od 4 do 21, a „Oddział Xięgarni” paragrafy 22-33. Co do drukarni, w umowie przewidziano jej rozwój z możliwością sprowadzenia większej liczby pras, papieru i różnego rodzaju czcionek. Dodano uwagę: „poprawność jest najcelniejszą zaletą druku", dlatego, jeżeli w jednym arkuszu znajdzie się cztery lub pięć omyłek, „arkusz takowy przyjęty być nie powinien”. W przypadku jakiegokolwiek sporu wynikającego z przestrzegania kontraktu przez obie strony, rozjemcą i pośrednikiem ma być wizytator szkolny Jan Nepomucen Wyleżyński, a organem rozstrzygającym Sąd Uniwersytetu Wileńskiego. Umowę na prowadzenie tak drukarni, jak i księgarni zawarto na 12 lat, to jest do 15 marca 1831 r., a w jej przedłużeniu Glücksberg będzie miał pierwszeństwo przed konkurencją. Kontrakt ten został zaakceptowany i potwierdzony przez księcia kuratora Adama Jerzego Czartoryskiego ${ }^{19}$.

Wracając do osoby Natana Glücksberga, to ciekawą anegdotę związaną z nim zanotował Franciszek Kowalski, który wspomina: „Raz mi opowiadał stary Glücksberg, jaki mu honor uczyniono na jednej stacyi pocztowej pomiędzy Uściługiem a Łuckiem, kiedy pierwszy raz wyjeżdżał z Warszawy do Krzemieńca w celu założenia tam księgarni. Miał on z Warszawy paszport, w którym było napisano „typograf Glücksberg” itd. Na poczcie, gdzie mu miano przemienić konie, pisarz przeczytawszy słowo typograf, kazał mu z największym uszanowaniem i pośpiechem zaprząc jak najlepsze konie, tłumacząc pocztylionom, że ten pan więcej znaczy niż graf, bo to nie graf, ale typograf"20.

Nie jest sprawą jednoznaczną jakość druku książek wychodzących z krzemienieckiej drukarni Glücksberga. Joachim Lelewel ocenia ją zdecydowanie negatywnie, pisząc: „Znaleziony giser krajowy wycinał na nie źle pojedyncze litery, nie trafiał do należytego ich w jedną harmonią kształcenia. Nie dość tresowany druk został na nowych prasach nieszykownie aż do niezgrabności użyty. Wszystko dowodziło gorliwość, ale nietrafność i nieświadomość"21. Wydaje się, że opinia Lelewela jest krytyczna. Biorąc dziś do ręki książki, które wyszły spod krzemienieckich pras, nie można stwierdzić nic na ich niekorzyść w porównaniu z książkami innych polskich ówczesnych oficyn.

Dochody, jakie uzyskiwali Glücksbergowie ze swej drukarskiej działalności w Krzemieńcu, były znacznie niższe niż się spodziewali. Pisał o tym Natan do księcia Adama Jerzego Czartoryskiego. Sytuacja zmuszała ich do ograniczania autorskich honorariów ${ }^{22}$.

Spośród 141 zarejestrowanych pozycji książkowych, 80 pojawiło się, gdy drukarnia znajdowała się pod kierownictwem Alojzego Osińskiego, resztę, czyli 61 zrealizowali Glücksbergowie. Dorobek drukarni krzemienieckiej Kazimierz Orzechowski podzielił na 7 grup. Pierwszą z nich stanowiły pozycje dokumentujące funkcjonowanie Gimnazjum, a od 1819 r. Liceum - programy nauczania, szkolne i biblioteczne statuty, sprawozdania finansowe i inne. Druga grupa obejmowała podręczniki, np. Początki algebry Grzegorza Hreczyny, Grammatyka dla

\footnotetext{
19 Biblioteka Uniwersytetu Wileńskiego, rkps F2-KC 305, s. 225-249.

20 F. Kowalski, Krzemieniec i krzemieńczanie w latach 1819-1823, [za:] Krzemieniec. Ateny..., S. 498 .

21 J. Lelewel, Bibliograficznych..., t. 1, s. 226.

22 K. Orzechowski, Szkilna drukarnia i knigarnia w Kremency (1811-1832), [w:] Volinski Afiny 1805-1933, red. S. Makowski, V. Sobczuk, Tarnopol 2006, s. 239-240.
} 
szkół narodowych dla III klas Onufrego Kopczyńskiego, czy Francuska gramatyka Jana Mikołaja le Forta. Następna grupa to dzieła naukowe, dysertacje autorstwa krzemienieckich profesorów lub przekłady z języków obcych przez nich dokonane. Czwarta grupa publikacji związana jest z funkcjonowaniem przyszkolnego ogrodu botanicznego, głównie prace jego opiekuna prof. Willibalda Bessera, katalogi roślin drukowane $w$ języku łacińskim i francuskim. Piąta grupa mieści mowy okolicznościowe, wśród nich znaczną liczbę poświęconych pamięci zmarłych dyrektorów szkoły Józefa Czecha i Alojzego Osińskiego, a przede wszystkim ku czci Tadeusza Czackiego. Ukazywały się także mowy wygłaszane z różnych szkolnych uroczystych okazji, jak uczniowskie popisy, powołanie nowego dyrektora czy rozdanie nagród i medali uczniom. Szósta grupa to druki związane z działalnością szkół w Okręgu, publikacje i programy nauczania, relacje z popisów, m.in. z Międzyrzecza, Klewania czy Teofipola. Do ostatniej grupy, nazwanej „Różne”, zalicza się poezja, np. Oda na śmierć Alojzego Felińskiego autorstwa Konstantyna Piotrowskiego, publicystyczne broszury, druki Towarzystwa Dobroczynności w Krzemieńcu i katalogi księgarskie Glücksbergów. Liczbę druków wychodzących z krzemienieckiej drukarni w danym roku obrazuje poniższa tabela:

Tabela 1.

\begin{tabular}{|c|c|}
\hline Rok & Łączna liczba publikacji \\
\hline 1811 & 13 \\
\hline 1812 & 13 \\
\hline 1813 & 7 \\
\hline 1814 & 8 \\
\hline 1815 & 8 \\
\hline 1816 & 5 \\
\hline 1817 & 6 \\
\hline 1818 & 9 \\
\hline 1819 & 11 \\
\hline 1820 & 14 \\
\hline 1821 & 11 \\
\hline 1822 & 8 \\
\hline 1823 & 8 \\
\hline 1824 & 6 \\
\hline 1825 & 4 \\
\hline 1826 & 1 \\
\hline 1827 & 2 \\
\hline 1828 & 1 \\
\hline 1829 & 1 \\
\hline 1830 & 4 \\
\hline 1831 & 11 \\
\hline Razem & 141 \\
\hline
\end{tabular}

Źródło: opracowanie własne. 
Z tabeli wynika, że drukarnia sprzed okresu prowadzenia jej przez Glücksbergów działała wcale prężnie. Najwięcej druków spod pras krzemienieckich wyszło jednak w pierwszych trzech latach prowadzenia jej przez tę drukarską rodzinę ${ }^{23}$.

Jak już było wspomniane, przy szkolnej drukarni założono też księgarnię. Podobnie jak drukarnię, nadzorował ją z ramienia szkoły rządca, czyli nadzorca, którym przez długi czas był Alojzy Osiński. Księgarnia znajdowała się początkowo obok drukarni, w domu Ożarowskich, poza murami szkolnymi, potem przeniesiona została wraz $z$ drukarnią $w$ inne miejsce. W księgarni, tłumnie odwiedzanej przez uczniów, nauczycieli i zwykłych obywateli miasta oraz przyjeżdżających gości, sprzedawano głównie wydawnictwa własne, ale też sprowadzane spoza Krzemieńca dzieła z literatury pięknej, prace naukowe oraz wydawnictwa Glücksberga drukowane w Warszawie i Wilnie. W opinii współczesnych, księgarnia miała obroty porównywalne do sklepów z popularnymi towarami. Księgarnia szkolna stała się nawet swego rodzaju klubem literackim, gdzie obok przeglądania i kupowania książek, odbywały się nawet zebrania naukowe i literackie, w czasie których wygłaszano prelekcje i recytowano utwory literackie ${ }^{24}$. Te spotkania porównywano czasem do posiedzeń Warszawskiego Towarzystwa Przyjaciół Nauk, na których prelekcje wygłaszali szkolni profesorowie ${ }^{25}$. Jak wspomina cytowany już pamiętnikarz Franciszek Kowalski, „stary” Glücksberg, czyli Natan, rzadko bywał w Krzemieńcu, osadziwszy w swoim zastępstwie syna Krystiana Teofila, „na stagnację księgarską wcale żalić się nie mógł".

W księgarni za ladą, pod nieobecność Teofila, stawali pozostali bracia - Gustaw Leon lub Emanuel August. O tym drugim Kowalski pisze: „chłopiec niezmiernych naukowych zdolności, ale wielki w handlu księgarskim niedbalec, który chodził na lekcje do liceum i bardziej pilnował kursów szkolnych, niż powierzonej sobie księgarni. U niego ciągle prawie trwał kongres literatów i nieliteratów, podlewany herbatą i winem"26.

Natan Glücksberg, obejmując drukarnię i księgarnię przy szkole w Krzemieńcu, zadbał o powszechne powiadomienie mieszkańców okolicy o tym fakcie. Otóż wydał druk, datowany na 7 października 1818 r., który zachował się do dziś wśród korespondencji księcia Adama Jerzego Czartoryskiego. Powiadamiał, że otrzymał od księcia A. J. Czartoryskiego, kuratora Uniwersytetu Wileńskiego i szkół z tego okręgu, tytuł księgarza i typografa Gimnazjum Wołyńskiego. W jego księgarni można nabyć „wszystkie książki do nauk po szkołach tych gubernii używane, jako też wybór najlepszych dzieł zagranicznych". Udogodnienia ze szkoły gimnazjum i jego zawodowe kontakty umożliwiają ceny ,jak najumiarkowańsze”. Obiecał, że sprowadzane do księgarni w Krzemieńcu książki będą tylko o 10 procent droższe niż w Warszawie czy za granicą ziem polskich. Natan Glücksberg wyraził nadzieję, że książki przez niego sprzedawane będą się cieszyły „częstym pokupem", co wynagrodzi mu niskie ceny ${ }^{27}$.

\footnotetext{
${ }^{23}$ K. Orzechowski, Szkilna drukarnia..., s. 241-242.

${ }^{24}$ A. Szmyt, Gimnazjum i liceum..., s. 203-204.

${ }^{25}$ M. Krzemińska, Paweł Jarkowski - bibliotekarz krzemieniecki, [w:] Krzemieniec. Ateny...,

${ }^{26}$ F. Kowalski, Krzemieniec i krzemieńczanie..., [w:] Krzemieniec. Ateny ..., s. 498-499.

27 Bibl. Czart., rkps 5455, k. 177.
} s. 173. 
Dopiero 30 maja 1822 r. książę kurator Adam Jerzy Czartoryski zezwolił Glücksbergowi na umieszczenie księgarni i drukarni ściśle przy gmachu Liceum Krzemienieckiego, „w murach przez Sobańskiego odstąpionych za opłatą szóstego procentu od sumy jaka na pobudowanie tego mieszkania wydaną będzie". Wstępnie ustalone koszty jednakże wzrosły, o czym księgarz poinformował księcia w liście z 27 listopada 1823 r., pragnąc renegocjować umowę. Uważał, że opłaty, jakie musi wnosić za zajmowanie lokalu na księgarnię, nie są sprawiedliwe. W lokalu tym znajdują się bowiem nie tylko jego książki, ale też będące własnością Liceum. Zaproponował, że może płacić za to pomieszczenie nie więcej niż 200 rubli srebrem ${ }^{28}$.

Glücksbergowie sprzedawali książki nie tylko w księgarni w Krzemieńcu, ale prowadzili także handel obwoźny, nawet po dość odległych stronach zachodnich guberni. Józef Korzeniowski wspomina, że jeszcze jako uczeń Liceum Krzemienieckiego często widział Krystiana Teofila Glücksberga, jak pomagał w pracy swemu ojcu, rozwożąc książki po dworach i dworkach Podola. Jego zasługą było np. kolportowanie tomików Ballad i romansów Adama Mickiewicza, szczególnie podczas jarmarków w Berdyczowie. Korzeniowski mimo to nie był dobrego zdania o Krystianie Teofilu, pisząc, iż ten księgarz od najmłodszych lat przejawiał niezwykłą przebiegłość, chciwość i bezwzględność ${ }^{29}$.

Cytowany już pamiętnikarz Franciszek Kowalski potwierdził, że Krystian Teofil Glücksberg handlował książkami w Berdyczowie i zacytował jego wypowiedź podczas ich osobistego spotkania: „Ja byłem z książkami na Podolu, w różnych domach i moja bryka już próżna; wyprzedałem wszystkie prawie książki i wracam do Krzemieńca"30.

W ofercie handlowej w Krzemieńcu Glücksbergowie mieli m.in.: Bajki i przypowieści Juliana Ursyna Niemcewicza, Amelia matką i Pamiątka po dobrej matce Klementyny z Tańskich Hoffmanowej, Pielgrzym w Dobromilu Izabeli Czartoryskiej, Jeometrię dla szkół wojewódzkich ks. Dąbrowskiego, Rys historyi polskiej J. Miklaszewskiego czy Zasady arythmetyki z tabellami1 ${ }^{11}$. Ogólnie ujmując, w księgarni Glücksbergów można było nabyć klasykę literatury pięknej, natomiast romantyczne utwory stanowiły mało znaczący margines. Znajdowały się tam m.in. Bajki Jean'a de La Fontaina, dramaty Moliera i Jean'a Baptiste Racine'a, prace Nicolasa Boileau, utwory największych myślicieli, Kodeks Napoleona, dzieła greckich i rzymskich klasyków. Spory procent stanowiły wydawnictwa francuskojęzyczne. Książki w języku polskim sprowadzano z Warszawy, Krakowa, Wilna, a także Wrocławia. Były to utwory Ignacego Krasickiego, Juliana Ursyna Niemcewicza, Malwina Marii Wirtemberskiej, Igraszki wierszem i prozą Franciszka Karpińskiego, Chemia Aleksandra Chodkiewicza, Historia polskiej literatury Feliksa Bentkowskiego, ponadto Słownik roślin Linneusza czy Duch chrześcijańskiej wiary François-René Chateubrianda. Były do nabycia również różnego rodzaju mapy ${ }^{32}$.

28 Tamże, k. 271.

29 A. W. Kempa, Drugie spotkanie z Teofilem Glücksbergiem, „Księgarz” 1959, nr 9-10, s. 15.

30 F. Kowalski, Wspomnienia (1819-1823), Kijów-Warszawa 1912, s. 197.

31 Bibl. Czart., rkps 5455, k. 201.

32 K. Orzechowski, Szkilna drukarnia..., s. 238. 
Natan Glücksberg utrzymywał korespondencyjny kontakt z księciem kuratorem szkolnym Adamem Jerzym Czartoryskim. Na przykład w liście z 27 listopada 1827 r. wysłanym z Krzemieńca prosił go o wsparcie finansowe druku Dykcjonarza grecko-polskiego, którego druk się opłaci przy nakładzie 600 egzemplarzy. Jest szansa, że wydawnictwo to rozejdzie się w środowisku szkoły w Krzemieńcu i Uniwersytetu Wileńskiego ${ }^{33}$.

Natan Glücksberg nie dożył czasu wygaśnięcia umowy, które przypadało na 15 marca 1831 r., zmarł bowiem w Warszawie kilkanaście dni wcześniej - 3 mar$\mathrm{ca}^{34}$. Jakie były po tym fakcie losy drukarni i księgarni krzemienieckiej - nie wiadomo. Nie udało się odnaleźć wiadomości o być może odnowionym kontrakcie z którymś z jego synów, jeżeli taki kontrakt był zawarty.

Trzeba nadmienić, że w tym czasie Liceum Krzemienieckie, uprzednio Gimnazjum Wołyńskie, lata świetności miało już za sobą. Wskutek klęski suszy i epidemii cholery w Krzemieńcu i okolicy był to też trudny czas dla szkoły, którą opuścili uczniowie. Jej upadek spowodowały represje carskie po klęsce powstania listopadowego i przegranej wojnie polsko-rosyjskiej. Już 1 maja 1831 r. rozwiązany został Wileński Okręg Szkolny, co wiązało się z zamknięciem większości szkół polskich, przede wszystkim Uniwersytetu Wileńskiego, a także Liceum Krzemienieckiego. Tętniące życiem tzw. „Ateny Wołyńskie” popadły w ruinę. Biblioteka szkoły i wszystkie bogato wyposażone gabinety $i$ kolekcje licealne zostały przewiezione do Kijowa, zasoby finansowe zagrabione, tworząc podwaliny nowo założonego Uniwersytetu św. Włodzimierza ${ }^{35}$.

Z całą pewnością drukarnia i księgarnia Glücksbergów w Krzemieńcu przestały wówczas istnieć, pozostawiając tylko wspomnienie o dziele zapoczątkowanym przez Tadeusza Czackiego.

\footnotetext{
33 Tamże, k. 273.

34 H. Pfeiffer, K. Świerkowski, Glücksberg Natan..., s. 95.

35 A. Szmyt, Gimnazjum i Liceum Wołyńskie..., s. 314-316, 321-325.
} 